\title{
Stakeholder engagement in a water user association for agricultural irrigation management in the villages in Indonesia
}

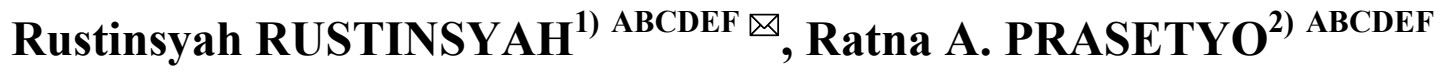

\author{
1) orcid.org/0000-0003-3535-6720; Airlangga University, Faculty of Social and Political Sciences, Dharmawangsa Dalam Selatan, \\ 60286, Surabaya, Indonesia; e-mail: rustinsyah@fisip.unair.ac.id \\ 2) orcid.org/0000-0003-4398-4700; Airlangga University, Faculty of Social and Political Sciences, Indonesia; \\ e-mail: ratna.aziz.prasetyo@fisip.unair.ac.id
}

For citation: Rustinsyah R., Prasetyo R.A. 2019. Stakeholder engagement in a water user association for agricultural irrigation management in the villages in Indonesia. Journal of Water and Land Development. No. 40 (I-III) p. 181-191. DOI: 10.2478/jwld-2019-0020.

\begin{abstract}
The fostering and empowerment of water user associations (WUAs) has been regulated by the Minister of Agriculture since 2012. However, the implementation of this guideline varies. Some water user associations have achieved improvement, while some others have not. This study discusses how a WUA in the villages that use Bengawan Solo River water has successfully managed the irrigation. One of the factors leading to the success of this WUA is the stakeholder engagement in the agricultural irrigation management and farm business. This study was conducted from June 2016 to June 2017 by employing a qualitative approach. It aimed to identify and understand the stakeholder engagement in agricultural irrigation management by: 1) conducting an analysis on stakeholder power and interest indices, 2) mapping the positions, responsibilities, and obligations of stakeholders, and 3) identifying the stakeholder engagement in agricultural irrigation management. The research results are as follows: a) the analysis using Likert scale showed that the power index reached a value of 0.76 , while the interest index reached a value of 0.78 ; b) the mapping of internal stakeholders, especially the responsibilities and obligations, has been regulated under the Articles of Incorporation of WUAs and obligations of external stakeholders, especially the government in making government regulations, irrigation infrastructure support, and flood prevention; c) cooperation of the stakeholders has an important role in the agricultural irrigation management and in solving the problems faced by WUAs.
\end{abstract}

Key words: agricultural irrigation management, Indonesia, rural area, stakeholder engagement, water user association

\section{INTRODUCTION}

The government has set a program to realize national food self-sufficiency. However, Indonesia - an agriculturebased country - still imports some commodities, especially rice, to date. According to the data of the Central Agency of Statistics (BPS), the amount of imported rice in the period January-February reached 14,473 tons, which is equivalent to USD 11.94 million. The rice is imported from various countries such as Pakistan, India, China, Thailand, and Vietnam [IDRIS 2017]. The policy of rice import was made on the grounds of the fact that the domestic rice productivity has not sufficed. One of the reasons for the low domestic productivity is crop failure. Most of the time, crop failure is caused by water scarcity. Water issue has become an intriguing theme in the economic, political, and social debates [EL CHAMI et al. 2011]. Some matters related to water issue are water scarcity [YANG et al. 2013], population and economic growth [ALCAMO et al. 2007], food trade and production [KASAAI 2014], competition for water, and water management systems [DE FRAITURE, WICHELNS 2010].

An effort that can be made in order to meet the need for water for rice crops in the villages within Bengawan Solo River Basin is using river water with water pump. For the pump technology to be implemented, fund support and 
participation of the community, private institutions or the government are important. To tackle this water issue, an irrigation system should be developed by involving the community through the Participatory Irrigation System Development and Management (PPSIP). Therefore, the Empowerment of Water Users (P3A) or Water User Association (WUA) is established.

WUAs (Water User Association) is a village-scale irrigation management organization. The importance of irrigation management in Indonesia is shown by the number of legal frameworks related to it, which include the following:

- Undang-Undang No. 7/2004,

- Peraturan Pemerintah No. 20/2006,

- Peraturan Menteri Pekerjaan Umum No. 31/PRT/M/ 2007 ,

- Peraturan Menteri Pekerjaan Umum No. 32/PRT/M/2007.

WUAs have been considered successful in managing agricultural irrigation in their respective regions. This success is proven by the sufficient availability of water for agricultural needs, which leads to rice productivity of the research area that reached 10-14 $\mathrm{t} \cdot \mathrm{ha}^{-1}$. The income generated by WUAs from their members' contribution can be used for incurring operational expenses and for supporting the construction of better irrigation infrastructure in rural areas. The success of irrigation management goes hand in hand with the internal and external stakeholder involvement in managing the agricultural irrigation. Therefore, this paper outlines this question: "How is the stakeholder engagement in agricultural irrigation management in the villages within Bengawan Solo River Basin and the social network implemented to achieve rural development?"

\section{WATER USER ASSOCIATIONS FOR MANAGING AGRICULTURAL IRRIGATION}

A Water User Association (WUA) is established with members comprising farmers. A WUA is a social, economic, cultural water user organization that is environmentally friendly and based on mutual aid. In some regions, this irrigation management institution is known in different names or terms. For example, in East Java it is known as HIPPA (Himpunan Petani Pemakai Air), in Bali it is known as Subak, and in West Java it is known as Mitra Cai. WUAs can be classified into four, namely: (1) Water User Association; (2) Water User Association Affiliation; (3) Parent Water User Association; (4) WUAs Federation. The guidelines for fostering and empowering water user association is regulated under the Peraturan Menteri Pertanian No. 79/Permentan/OT.140/12/2012.

A WUA serves as an institution that distributes water to the agricultural lands in its region. According to the World Bank, there are five principles for establishing of Water User Associations (WUAs), namely: (1) there should be adequate and reliable water supply, (2) the WUAs should be organized hydraulically (not administratively), (3) leaders should be elected and WUAs management and decision making should be with the farmers (without local government interference), (4) water should be charged volumetrically (not according to land area), and (5) the WUAs should have the right to collect water fees [WANG et al. 2010].

In managing agricultural irrigation, WUAs engage external and internal stakeholders. A stakeholder is an individual or a group influencing and/or being influenced by something in order to attain a certain goal. Internal stakeholders are the managers and usually comprise the villagers. Internal stakeholders are the managers of the WUAs and the organizations supporting the farm business activities. On the other hand, external stakeholders are the stakeholders outside the management. Some external stakeholders are from the village, some others are from the outside. Thus, the managers receive incentives derived from some of the funds collected from the members. This is in line with the opinion of SMALL and CARRUTHERS [1991], who stated that agricultural irrigation financing is internally derived from the farmers' contribution for financing the water to be used. This condition leads to strong accountability, which enhances the performance in the distribution of water supply to farmer-owned lands. The engagement of local community (village) in managing the irrigation system may lower the expenses incurred by the government and maintain the sustainability of regional irrigation system.

Stakeholders have position, power, and interest related to a particular intention [FREEMAN 1984]. On the other hand, GRIMBLE and WELLARD [1997], emphasizes on the important position and influence of stakeholders. In managing agricultural irrigation and implementing programs, WUAs stakeholders cooperate in a social network to achieve their goals. The social network, cooperation, and participation of the stakeholders are referred to as social capital. According to BoURDIEU [1983], social capital is a set of resources and potential that are related in a collectively acknowledged social network to achieve a goal. PUTNAM et al. [2000] argued that social capital consists of beliefs and norms regulating the existence of a network to enhance efficiency and collective initiative of a social organization. Social capital is comprised of a number of dimensions, namely civic participation, social network and social support, social participation, reciprocity and trust, and views of the local area [FOXTON, JONES 2011]. GRANOVETTER [1973] identified that social capital forms consist of social relations in a network and in performing their functions, the nature of some relations is strong and the nature of others is weak. FUKUYAMA [1995] argued that social capital is necessary for successful development, but a strong rule of law and basic political institutions are necessary to build social capital. A hybrid social capital as a combination of bonding, bridging, and linking social capital plays a role in the effort to improve the implementation of subsidized fertilizer in Pelem village, Pare District, Kediri Regency [RUSTINSYAH 2015].

Similarly, social capital which constitutes the social relation network of stakeholders has some functions in a social organization in promoting collective initiatives. The functions and roles of the elements of stakeholders in a network include the action in participation, support, and mutual exchange cooperation followed by norms and beliefs between one another to achieve a particular goal. 
Stakeholders have a social network to develop and overcome problems faced by WUAs.

Some literature stated that the success of agricultural irrigation management through WUAs brings about some changes in some ways, including increasing agricultural productivity, increasing income, and encouraging technological use as an effort to boost the growth of agricultural productivity [MORRIS et al. 1999; World Bank 2012]. Water use in agricultural irrigation in river basin villages with pump technology is considered beneficial for sustainable agricultural development. According to EDQUIST [1985], for development to be productive, farmers must be involved in the application of the technology. In addition, ARIEL [2016] showed that investment in advanced irrigation technology in highly recommended for the success of managing farms which in turn will support rural development.

\section{METHODS}

\section{RESEARCH AREA}

This study was conducted at the WUAs in some villages within Bengawan Solo River Basin, Plumpung District, Tuban Regency, East Java (111 $30^{\circ}-112^{\circ} 35^{\prime}$ E and $\left.6^{\circ} 40^{\prime}-7^{\circ} 18^{\prime} \mathrm{S}\right)$. There were six WUAs in the district that used the Bengawan Solo River water for agricultural irrigation, namely (1) WUA in Bandungrejo village; (2) WUA in Plandirejo village; (3) WUA in Klotok village; (4) WUA in Kedungrejo village. WUA in Magersari village and Plumpang village were managed by the WUAs in Bandungrejo (Fig. 1).

One of the WUAs that experienced advancement and success was WUA Sekarpadi in Bandungrejo Village. WUAs Sekarpadi also managed the agricultural irrigation from Magersari Village and Plumpang Village. The success of this WUAs was evidenced by the ownership of a fairly considerable financial source that could be used for implementing agricultural irrigation management program and solving problems. According to the Progress Report of WUAs Sekarpadi in the Management Period 2015-2017 [Laporan Kemajuan... 2017], the financial position of this WUA stood at Rp 743,842,355 (approximately USD 55,000). The following is Table 1 Financial Position of WUAs Sekarpadi.

Bandungrejo Village is situated in Bengawan Solo River Basin. Bengawan Solo River Basin comprises Upstream Bengawan Solo Sub-River Basin, Kali Madium Sub-River Basin, and Downstream Bengawan Solo SubRiver Basin. Kali Madiun Sub-River Basin covers an area of $6,072 \mathrm{~km}^{2}$, and Downstream Bengawan Solo Sub-River Basin covers an area of $3,755 \mathrm{~km}^{2}$. Administratively, Bengawan Solo River covers 17 regencies and three cities, including Boyolali, Sukohardjo, Wonogiri, Blora, Rembang, Ponorogo, Madiun, Magetan, Ngawi, Bojonegoro, Tuban, Lamongan, Gresik, and Pacitan. The downstream area of Bengawan Solo River is occupied by densely populated settlements that delta cities are formed, including the cities of Bojonegoro, Tuban, Lamongan, and Gresik.

These days, the estuary area of Bengawan Solo River floods frequently due to the overflow of the river, especial-

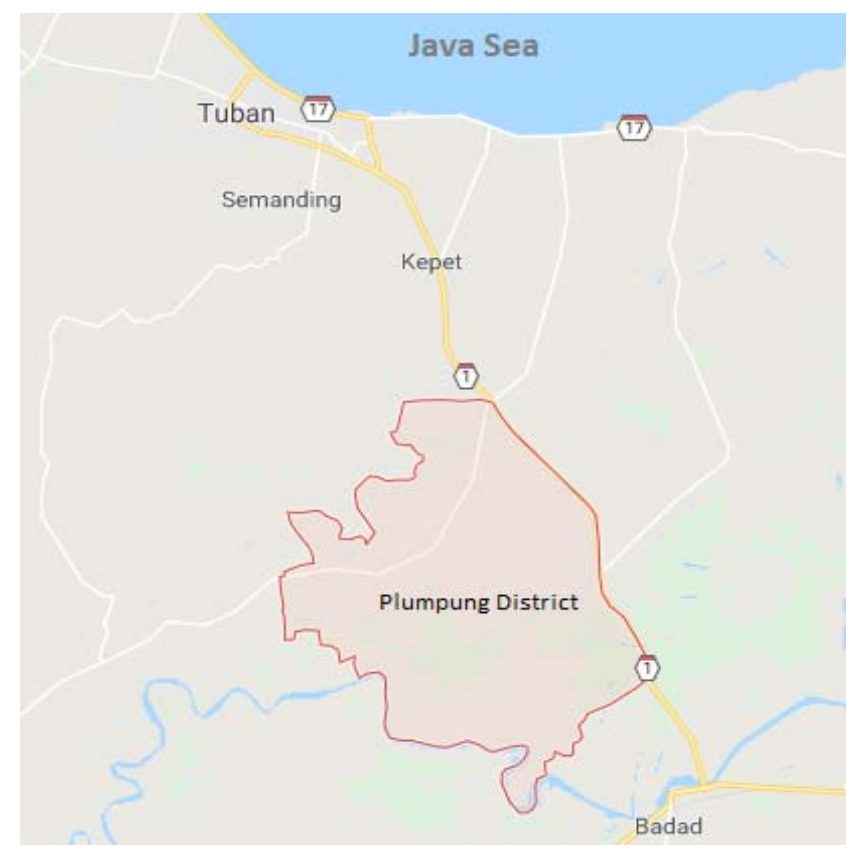

Fig. 1. Research area;

source: own elaboration based on Google Maps

Table 1. Financial position of Water User Association (WUAs) Sekarpadi

\begin{tabular}{|c|l|r|}
\hline No & WUA's financial condition & Total (Rp) \\
\hline 1 & $\begin{array}{l}\text { operational balance of MP II of the period 2015- } \\
2017\end{array}$ & $37,819,500$ \\
\hline 2 & $\begin{array}{l}\text { oil fuel and electricity of MP II of the period } \\
2015-2017\end{array}$ & $229,551,000$ \\
\hline 3 & the outcome of WUA Sumber Rejeki development & $7,969,680$ \\
\hline 4 & the outcome of WUA Mekar Sari development & $12,427,415$ \\
\hline 5 & $\begin{array}{l}\text { sub enterprise unit of WUA Sekarpadi of MP of } \\
\text { the period 2015-2017 }\end{array}$ & $193,272,500$ \\
\hline 6 & cash ratio of WUA Sekarpadi & $264,489,189$ \\
\hline 7 & Down payment of pipe sale to Plumpang & $40,000,000$ \\
\hline \multicolumn{2}{|l|}{ Wotal } & $785,529,284$ \\
\hline WUA loss (2015-2017) from harvest & $-50,686,929$ \\
\hline \multicolumn{2}{|l|}{ Total revenue (May 2017) } & $734,842,355$ \\
\hline
\end{tabular}

Explanations: MP $=$ harvest season (Ind. Musim Panen), Rp 10,000 = USD 0.7

Source: Laporan Badan... [2017].

ly Bojonegoro, Tuban, and Lamongan cities. Likewise, Bandungrejo village, Plumpang District, Tuban Regency has been inundated during the raining seasons. The flood season usually starts from December and ends in April. However, the exact time may be later or earlier. In 2017, the flood in most part of Bandungrejo village lasted until May 2017. If it is flooding, farm business on the agricultural lands within the proximity of the river cannot be conducted due to the inundation.

When it is flooding, pumps are used for draining the water from the agricultural lands to the river. As for the areas far away from the river basin, agricultural business can be conducted by relying on the rainwater and by using rice cropping pattern, while in February horticulture is performed (planting watermelon, melon or pulses like maize and soy). 
WUAs Sekarpadi managed the agricultural irrigation of 206 ha of agricultural area, comprising 193 ha of agricultural area in Bandungrejo village, 5 ha in Plumpang village, and 8 ha in Magersari village. WUAs Sekarpadi had 638 members. The WUA members from Bandungrejo village had member cards, while those from Plumpang village and Magersari village did not. WUA members were farmers who cultivated the agricultural land. Some of them rented the land, while some others owned the land. For this reason, WUA members may change from year to year.

\section{TECHNIQUES OF DATA COLLECTION}

Data collection in the field was conducted in some ways.

1. The data were collected by conducting observations and participatory observations in order to see directly the conditions of the work system of WUA in distributing water, the conditions of irrigation networks, and the stakeholders performing the tasks. There were three irrigation networks, namely primary, secondary, and tertiary irrigation networks. The maintenance of the irrigation network was performed by the government, the local community, and the WUAs.

2. The data were collected by conducting interviews and in-depth interviews with internal and external WUAs stakeholders regarding the water distribution, irrigation network maintenance, and activities related to farm business. The external stakeholders consisted of Water Resources Division of the Office of Public Works, Office of Agriculture of Tuban Regency, Farmer Groups in the villages, village apparatus in the agricultural sector, and water users as WUAs members. Internal stakeholders consisted of the WUAs managers and members, head of village and village apparatus, and other stakeholders such as farmer groups, agricultural product buyers, fertilizer sellers, and villagers as the workers in the agricultural sector.

3. The data were collected by holding an FGD (Focus Group Discussion) between the members and administrators to obtain information regarding the issues related to water distribution and management as well as other farm business issues.

4. The data were collected by consulting documents related to the management of irrigation and other water sources, WUAs progress reports, and so forth, to assist in the analysis of the data.

\section{TECHNIQUES OF DATA ANALYSIS}

1. The data analysis was intended to understand the ethnographic data consisting of the transcription of interviews with the stakeholders, results of FGD (Focus Discussion Group), journal, yearly reports, and the results of other observations. The data analysis was carried out in two stages. The first stage was classifying the data in the forms of interview transcription, journal, and yearly reports of WUAs management. The second stage was interpreting the data, then, developing a narration to obtain information regarding the success and problems of WUAs in water management as well as its impact on the village development.
2. To identify the stakeholders in the management of water for agricultural irrigation, a Likert scale was used. The results of the Likert scale were calculated using statistical calculation to determine the extent of stakeholder power and interest in the agricultural irrigation management.

\section{RESULTS AND DISCUSSION}

\section{OVERVIEW OF THE WUAS}

To discuss the engagement of WUAs stakeholders in managing irrigation, the case of WUA Sekarpadi in Bandungrejo Village was taken as an example. WUAs Sekarpadi was one of the WUAs that successfully managed agricultural irrigation in Bandungrejo village, Plumpang District, Tuban Regency. The agricultural system was implemented through the use of Bengawan Solo River water with pump, and the management was conducted by WUA.

WUAs Sekarpadi had 638 farmers and an agricultural area of 206 ha, consisting of 193 ha in Bandung village, 5 ha in Plumpang village, and 8 ha in Magersari village. The WUAs work system involved internal and external stakeholders. The following is Figure 2, which is about WUAs Sekarpadi's Framework.

WUAs work system in the agricultural irrigation management in the village is influenced by internal and external factors. The following are the internal factors:

- organizational structure, the responsibilities and obligations of which have been regulated under the articles of incorporation;

- WUAs members as the sources of finance for WUAs management, which have been regulated under the Articles of Incorporation;

- engagement of local workers, both males and females, as the workers in the farm business and other works;

- participation of the local communities, e.g., mutual aid for infrastructure repair, flood problem solving, and so forth;

- the presence of farmer groups as the implementer of agricultural development program for farmers, e.g., subsidized fertilizer program, pest and disease eradication program, and so forth.

Meanwhile, external factors include the government policies concerning the environment, legal framework, physical and technological aspects in water use or water capacity, and socioeconomic conditions. Internal factors include local policies in the form of a guideline of the implementation of WUAs programs specified in the articles of incorporation, membership criteria, organization structure, internal stakeholders, and local wisdom. The external and internal factors influencing the work of WUAs certainly have an association with the roles of the stakeholders. Stakeholders are the individuals or groups influencing or being influenced by something for the achievement of certain goals. Furthermore, stakeholders have position, power, and interest related to certain intention [FREEMAN 1984]. Meanwhile, GRIMBLE and WELLARD [1997] emphasized on the important position and influence of stakeholders. 


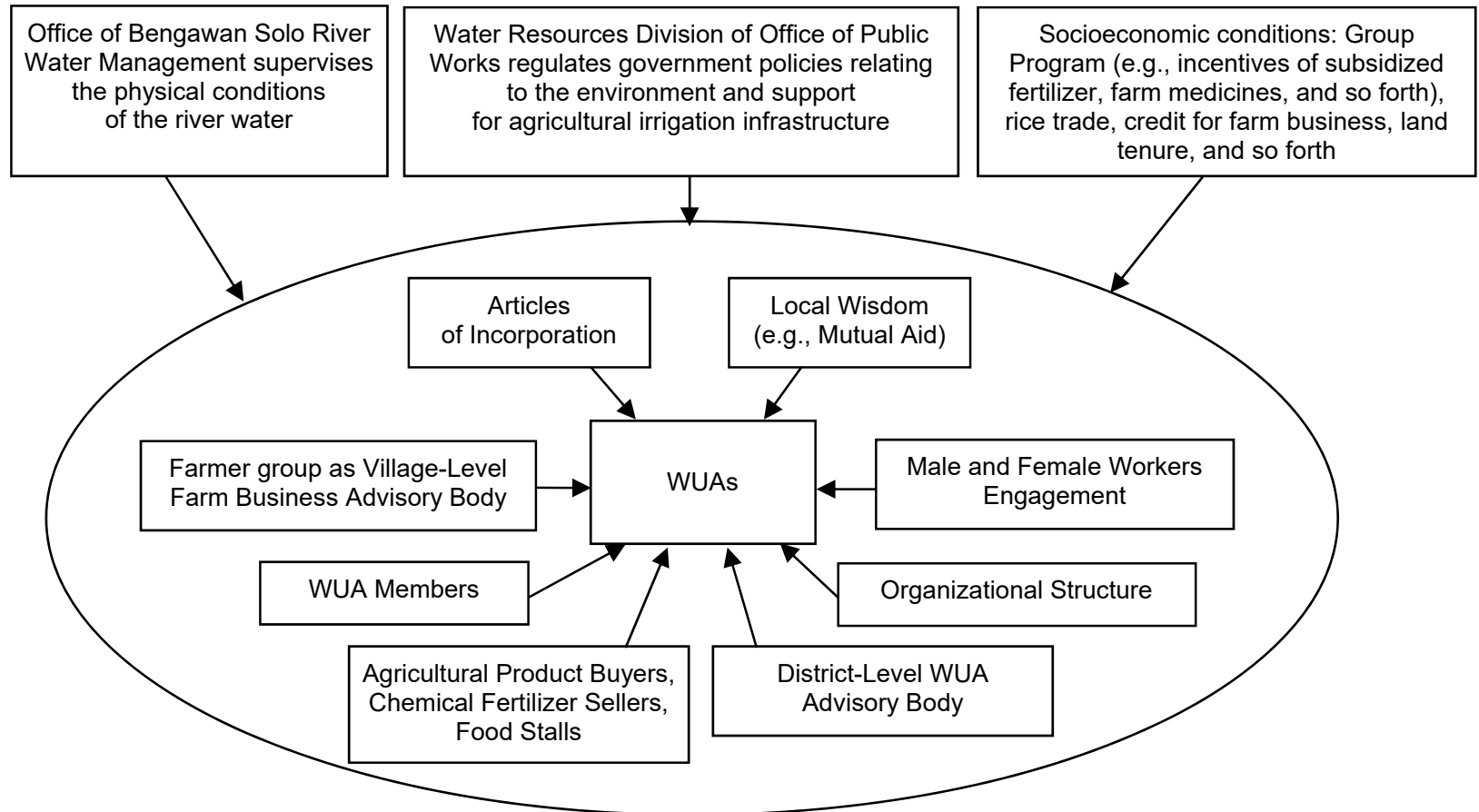

Fig. 2. The framework of WUAs (Water User Association) management; source: own elaboration

Internal stakeholders are the managers of WUAs and the organizations supporting the farm business. WUAs management has responsibilities and obligations in managing agricultural irrigation and supporting infrastructure, which have been regulated in the articles of incorporation. Internal stakeholders play an important role in the irrigation management. For this reason, the management receives incentives obtained from some funds collected from its members. The following is Table 2, which presents the allocation of income for cash and incentives of WUAs management.

Table 2. Allocation of net income of water user association (WUAs) in Harvest Season II (2015-2017)

\begin{tabular}{|c|l|c|r|}
\hline No & \multicolumn{1}{|c|}{ Description } & $\begin{array}{c}\text { Allocation of income } \\
\%\end{array}$ & $\begin{array}{c}\text { Total } \\
\text { Rp }\end{array}$ \\
\hline 1 & WUAs Sekarpadi cash & 40 & $83,084,490$ \\
\hline 2 & Management fee & 11 & $22,848,235$ \\
\hline 3 & Work group fee & 17 & $35,310,908$ \\
\hline 4 & Operator fee & 2 & $4,154,224$ \\
\hline 5 & Assisting Diesel operator fee & 1 & $2,077,112$ \\
\hline 6 & Driver fee & 1 & $2,077,112$ \\
\hline 7 & Supervisory Agency fee & 1.5 & $3,115,669$ \\
\hline 8 & Development fund & 15 & $31,156,684$ \\
\hline 9 & Social fund & 3 & $6,231,337$ \\
\hline 10 & Village cash & 3.5 & $7,269,893$ \\
\hline 11 & Honour fee & 5 & $10,385,561$ \\
\hline & Total & & $\mathbf{2 0 7 , 7 1 1 , 2 2 5}$ \\
\hline
\end{tabular}

Source: Laporan Kemajuan... [2017].

The incentive for the WUAs management is given in accordance with the opinion of SMALL and CARRUTHERS [1991], who mentioned that agricultural irrigation financing is internally derived from farmers' contribution for the water to be used. This condition leads to strong accountability, which results in increased performance in the distri- bution of water supply to the farmer-owned agricultural lands. Local community (village) engagement in the irrigation system management may reduce the expenses incurred by the government and maintain the sustainability of regional irrigation system.

External stakeholders take a part in supporting the success of agricultural irrigation water management. In accordance with the Regulation of the Minister of Agriculture Number 79/Permentan/OT.140/12/2012, the fostering, development, and empowering of WUAs are conducted by forming 1) Central Advisory Team; 2) Advisory Team at the Province Level; 3) Implementing Team at the Regency/Municipality Level; and 4) Implementing Team at the District Level. The teams at the district level are headed by the Technical Implementing Unit of Agriculture, and the Heads of Counselling Centre at District Level serve as the secretaries. Meanwhile, the members consist of the agricultural counselling coordinators, heads of village, and representatives of institutions relevant with the fostering and empowerment of district-level Water User Association.

In accordance with that regulation, the Water Resource Division of the Office of Public Works is part of the team related to the fostering and development of WUAs and is obliged to improve the primary and secondary irrigation networks. This is in line with the Government Regulation of the Republic of Indonesia No. 23 of 1982 on Irrigation Article 2 Paragraphs 2 and 3 as follows:

Paragraph 2: Irrigation water and irrigation networks, along with the complementary buildings within a tertiary plot, Village irrigation, and the management are assigned to water users or Village or relevant Subak, under the supervision of the Regional Government by bearing in mind the provisions herein.

Paragraph 3: The management of irrigation water and irrigation network, along with the complimentary buildings 
constructed by a legal entity, social body or natural person for the purpose of its business is assigned to the legal entity, social body or natural person in question by bearing in mind the provisions herein.

The Office of Agriculture plays a vital role in the success of farm business with its program of forming farmer groups in villages and directly assisted by FCOs (Field Counselling Officer). Some of the most important programs for farmer groups are the provision of fertilizer subsidy, food crop pest eradication, and so forth. For example, the Regulation of the Minister of Agriculture No. 60/SR.310/12/2015 specifies the types of subsidized fertilizers for food crops to be urea fertilizer, SP-36, ZA, and NPK, and the highest retail prices. Likewise, for the improvement of water supply to agricultural land, the Office of Bengawan Solo River Water Management works with the governments at district and village levels.

WUAs Sekarpadi was one of the WUAs that have successfully managed agricultural irrigation. This WUAs success in the agricultural irrigation management was proved by the following: (1) its financial position stood at Rp $734,842,355.00$; the money was saved in Bank Rakyat Indonesia; (2) in harvest season II, management period of 2015-2017, this WUA's net income reached Rp $462,616,825.00$. This income was derived from the contribution of each WUA member in the form of harvest commission, which was regulated in the articles of incorporation of this WUAs. The percentage of contribution has been specified in the articles of incorporation. The contribution of a WUA member for the agricultural land near the estuary was $10 \%$ of the harvest as the harvest was only $40 \%$ of the normal amount. A contribution of $14 \%$ was imposed to those whose harvest reached 10 tons or more per hectare. This contribution was in the form of share of rice harvest directly collected by a WUAs officer at the agricultural area. The rice was then sold to the buyers present at that place. The success of WUA Sekarpadi involved a number of stakeholders that had position, power, and interest.

\section{IDENTIFICATION OF WUAS STAKEHOLDERS: POWER AND INTEREST}

In managing the agricultural irrigation, WUAs engages internal and external stakeholders. According to the position, there are two types of stakeholder profiles, namely primary and secondary stakeholders. Primary stakeholders are the stakeholders that have the authority to influence change, policy, and implementation of agricultural irrigation management activities. Primary stakeholders include the WUAs core managers, head of village, WUAs members, and supervisory body in the village. Secondary stakeholders are the individuals, groups, or organizations that share the same view or position and are ready to join coalition to support a certain issue or activity. Secondary stakeholders may sit in the or out of the village. Secondary stakeholders including the head of farmer group, water resource division of the Office of Public Works of Tuban Regency Level II, Office of Bengawan Solo River Water Management, rice buyers, village apparatus, and public figures. The stakeholders engaged in WUAs have power and interest at different levels appropriate with their positions.

Stakeholders have the power to influence and govern the success of agricultural irrigation water management. According to MoRgenthaU [1997], power is the capability of a person or a group to influence another party in order to gain what the person or the group desires. This may be achieved by means of violence or non-violence to influence and govern. With regard to agricultural irrigation management, the influence of power is used for supporting the agricultural water distribution program and solving problems when a conflict or violation relating the procurement and distribution of water arises. Furthermore, MORGENTHAU [1997] mentioned the following indicators of stakeholder power:

- authority, which is the power given to an individual or a group, who, in performing the function to act, has the authority to make regulations to govern others;

- capability, which is the capability of a person or a group with skills to understand and provide relevant solutions;

- credibility, which is the condition in which one is trusted or held accountable, in which case the individual holds a reputation in solving problems;

- capacity, which is the ability of a person or a group (stakeholder) in absorbing, reviewing, analysing, and providing solutions for a problem;

- mass mobilization, which is the ability to mobilize the mass.

These power indicators have measures. The measures are identified in Table 3.

Table 3. Identification of the levels of stakeholder power

\begin{tabular}{|c|c|c|c|c|c|}
\hline \multicolumn{5}{|c|}{ Power indicators } & \multirow{2}{*}{$\begin{array}{c}\text { Level } \\
\text { category }\end{array}$} \\
\hline authority & capability & credibility & capacity & $\begin{array}{l}\text { mass mo- } \\
\text { bilization }\end{array}$ & \\
\hline$\sqrt{ }$ & $\sqrt{ }$ & $\sqrt{ }$ & $\sqrt{ }$ & $\sqrt{ }$ & very high \\
\hline$\sqrt{ }$ & $\sqrt{ }$ & - & $\sqrt{ }$ & $\sqrt{ }$ & high \\
\hline$\sqrt{ }$ & $\sqrt{ }$ & - & $\sqrt{ }$ & - & fairly high \\
\hline- & - & - & $\sqrt{ }$ & - & low \\
\hline
\end{tabular}

Source: own study based on power indicators of MORGENTAHU [1997].

Referring to MORGENTAHU [1997], as shown in Table 3 , and by using a Likert scale, this study found that the stakeholder power index in managing the agricultural irrigation reached a value of 0.76 or $76 \%$. Thus, the power index of WUAs in the agricultural irrigation management was high. Due to the big amount of the data, the details of the data are placed in the Data in Brief journal article cf. RUSTINSYAH [2018]. The high-power index shows that in managing agricultural irrigation, the stakeholders had worked hard in accordance with their positions, responsibilities, and obligations. Head of village, chairman of management, and supervisory body as the key players in the agricultural irrigation management in the village had very high power to determine the direction of WUAs success. They had the authority, capability, and ability to mobilize the mass to solve the problems related to water management and to lead the general meeting to plan work programs. 
Similarly, stakeholders had interest in the existence of WUAs in the agricultural irrigation management. According to BRYSON [2004], interest is the will and desire of a person or a group for an activity. WUAs stakeholders had varied interest. Some indicators of interest are hope, aspiration, and potential benefit. Based the tabulation of the data using a Likert scale, the stakeholder interest index reached 0.78 or $78 \%$. This means that the stakeholders had high interest in the agricultural irrigation management. The details of the data on this stakeholder interest indicators are also placed in the paper by RUSTINSYAH [2018].

\section{STAKEHOLDER: MAPPING AND FUNCTION}

In managing the agricultural irrigation, WUAs engages a number of internal and external stakeholders. The responsibilities and obligations of WUAs managers are specified in the Resolution of General Meeting of WUA Sekar- padi No. 03/1/HIPPA.SEKARPADI/2017 [Kasekapatan Rapat... 2017]. Meanwhile, the responsibilities and obligations of external stakeholders are specified in rules or only in agreement. According to BRYSON [2004], stakeholder position is divided into four, namely:

- subject, which is an organization which has great interest but small power. Subject is in an organization that is concerned about an activity;

- player, which is a person with great interest and great power. Players are seen as the main performer;

- context setter, which is a group that has great power but small interest as it is not directly associated with the water management activity;

- crowd, which is group of stakeholders that have small interest and small power.

The following is Table 4, which is about the levels, categories, functions, and responsibilities of stakeholders.

Table 4. The mapping of the stakeholder functions of water user association (WUA) Sekarpadi of Bandungrejo

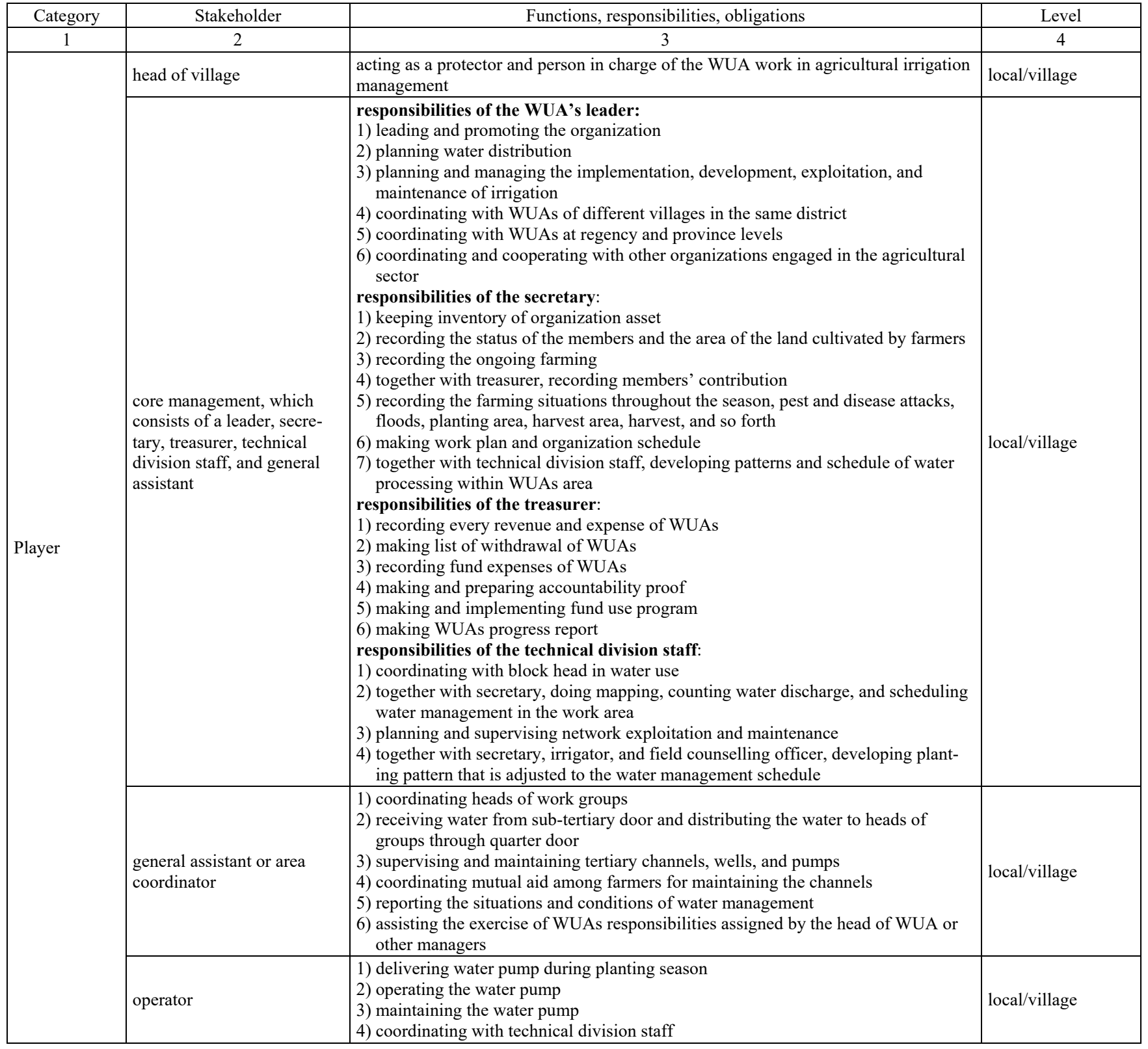


cont. Tab. 4

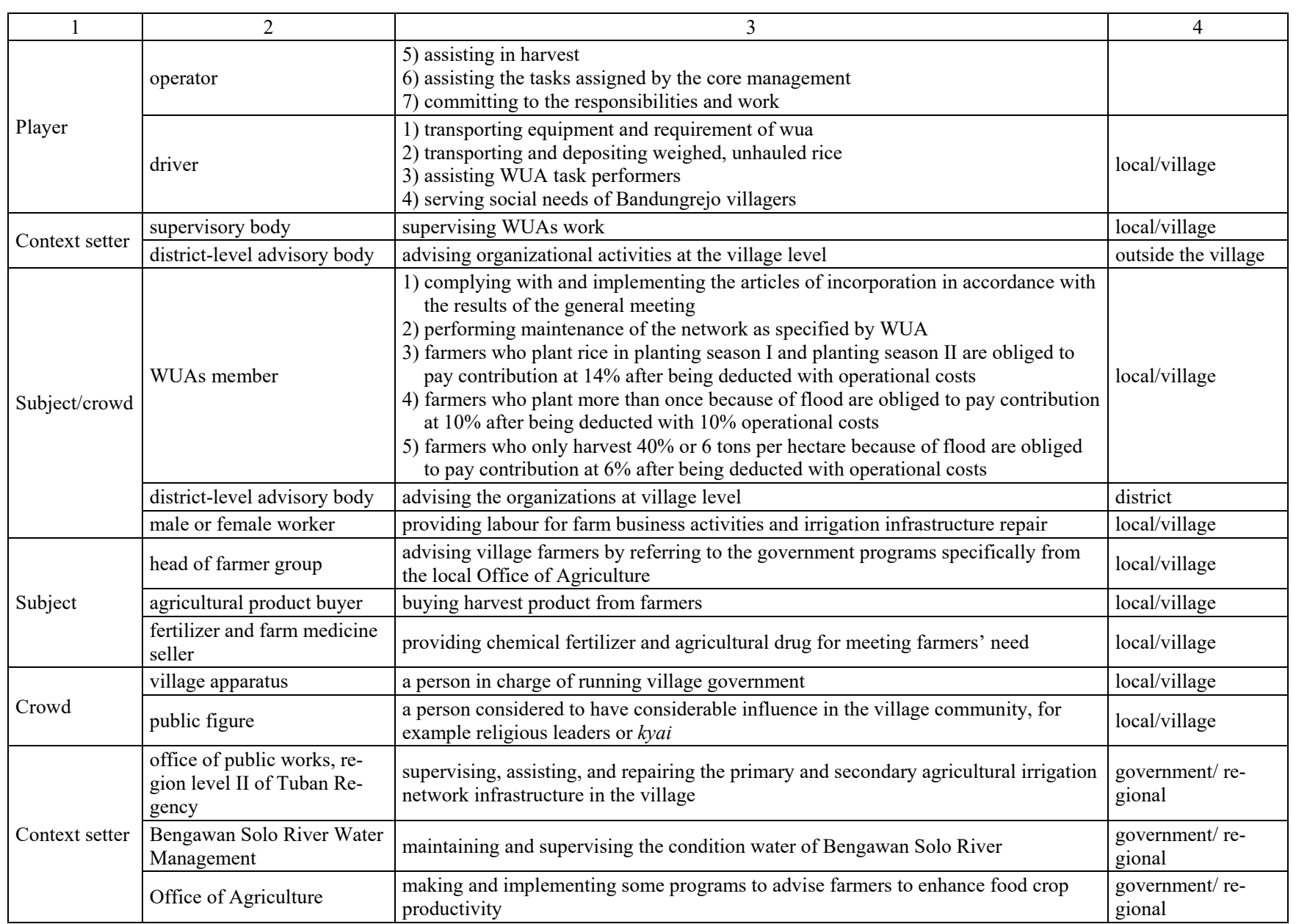

Source: own study and Anggaran Dasar... [2014].

For more information about the position of power and interest categories of the stakeholders of WUAs in managing agricultural irrigation, please refer to Figure 3 concerning the categories, position, power, and interest of WUA stakeholders below.

According to Figure 3, players consisted of internal stakeholders, namely head of village, leader and core managers of WUAs, operators and drivers, area coordinator, and heads of work groups. These stakeholders have great

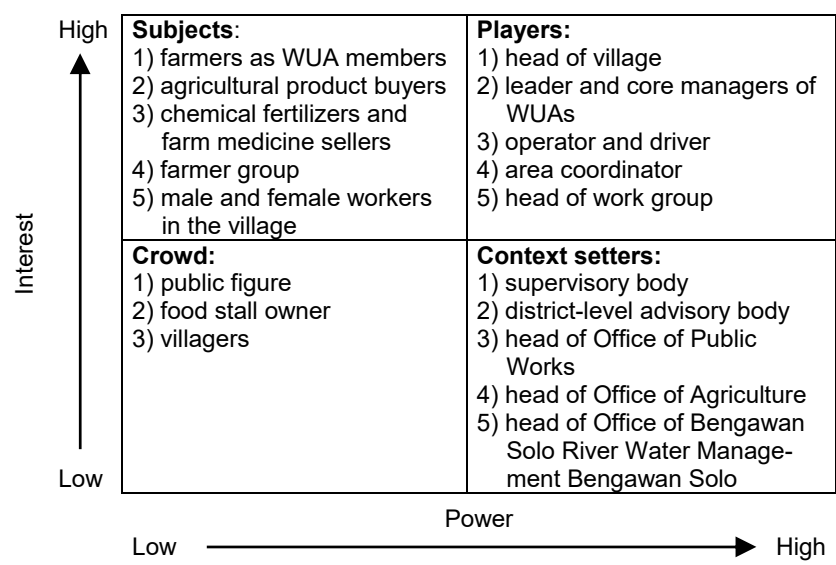

Fig. 3. Categories, position, power, and interest of WUA stakeholders; source: own elaboration power and great interest in the irrigation management as they are selected and trusted to manage the agricultural irrigation in the village. To implement those programs, budget plan is developed, then approved at the meeting attended by all managers, supervisory body, and members. They also make decisions to tackle the problems relating to water distribution and farm business activities.

Farm business activities are not separated from water distribution as the failure of farm business constitutes the failure in the irrigation management. For example, when there are pests or diseases attacking rice crops and causes harvest failure, they will have the power to make a program and make decisions to allow for immediate problem solving.

Subjects are some stakeholders who have great interest but small power, for example farmers as WUAs members, agricultural product buyers, chemical fertilizer and farm medicine sellers, farmer groups, and workers in the village. They have great interest in the success of the water management as the success will impact on their activities. For example, agricultural product buyers buy rice from farmers and WUAs as contribution from farmers for the irrigation water service. The amount of the contribution is specified in the articles of incorporation. According to the Laporan Kemajuan ... [2017], the contribution of the farmers as WUAs members amounted $167,397 \mathrm{~kg}$, which 
is equal to Rp 528,137,525. After deducted by the harvest cost, the net revenue of WUAs reached Rp 462,616,825. The average price of rice/unhulled rice per kilogram was Rp 3,155.

The agricultural product buyers are generally from the village. Usually they process paddy into rice by employing local male and female workers. The rice buyers are from Bandungrejo village; thus, the farmers of this village do not find any difficulty in selling the rice. The ease of selling the harvest yield causes the farmers in the village sell nearly all of the harvest, which will not cover the need for the next harvest.

WUAs members are farmers. They also rent or own agricultural lands. The WUA members may change from year to year. Some WUAs members are the managers of WUAs. The responsibilities and obligations of WUAs members are specified in the articles of incorporation. As WUAs members, they may protest when they are disadvantaged in the water management. For example, during a long rainy season, the rice crops are inundated and rot, and even attacked by pests or diseases. For that reason, farmers may protest to the WUA managers so that the water is drained from the agricultural area to the river immediately.

The external stakeholders from the government that have great power but low interest are:

1) Office of Public Works who have an obligation to repair primary and secondary irrigation network; this is in line with the Government Regulation of the Republic of Indonesia No. 23 of 1982 on Irrigation Article 2 Paragraphs 2 and 3; Office of Agriculture that has a program to guide farmers by forming farmer groups directly assisted by the field counselling officers. Some programs that directly benefit the farmers are the provision of fertilizer subsidy, food crop pest eradication, and so forth. According to the Regulation of the Minister of Agriculture No. 60/SR.310/12/2015, the types of subsidized fertilizers for food crop are urea fertilizer, SP36, ZA, and NPK, at the highest retail prices; in 20162017, the Office of Agriculture gives out aids through farmer groups in the form of subsidized fertilizer and pest and disease eradication; farmer groups have programs related to agricultural irrigation management; the success of farm business impacts on the development in the village;

2) The Office of Bengawan Solo River Water Management plays a vital role in the water distribution; for example, during a long dry season, the water discharge of Bengawan Solo River decreases; thus, WUA managers consult this office about it; some literature mentioned that the success of agricultural irrigation management through WUAs brings about some changes in different ways such as increasing agricultural productivity, increasing income, encouraging technological use as an effort to boost the agricultural productivity [MORRIS et al. 1999; World Bank 2012].

\section{THE IMPORTANCE OF STAKEHOLDERS - COOPERATION IN OVERCOMING PROBLEMS}

Cooperation between stakeholders is necessary for the exercise of responsibilities and obligations. This cooperation is needed for managing agricultural irrigation and overcoming problems relating to farm business. The success of WUAs in managing irrigation is related to the success in producing rice crops. The success in farming will have a correlation with the source of income of WUAs. The following is Table 5, which is about the problems faced by WUAs as an agricultural irrigation manager.

Table 5. Problems and strategies for overcoming the problems occurring in the harvest season Water Management (2016-2017)

\begin{tabular}{|c|c|c|}
\hline $\begin{array}{l}\text { Issues relating to } \\
\text { irrigation water } \\
\text { management }\end{array}$ & Indicators & Strategies \\
\hline Flood & $\begin{array}{l}\text { flood occurs near the } \\
\text { estuary during the rainy } \\
\text { season (December-April), } \\
\text { making the field inundated } \\
\text { by water and causing } \\
\text { damage to the crops as } \\
\text { well as pests and diseases }\end{array}$ & $\begin{array}{l}\text { 1) water drainage to } \\
\text { the river using water } \\
\text { pump } \\
\text { 2) having mutual aid } \\
\text { with the people of the } \\
\text { village and the } \\
\text { neighbouring villages }\end{array}$ \\
\hline Worker & $\begin{array}{l}\text { lack of workers when rice } \\
\text { harvest happens at the } \\
\text { same time }\end{array}$ & $\begin{array}{l}\text { bringing in workers } \\
\text { from the neighbouring } \\
\text { villages with lump } \\
\text { sum wage } \\
\end{array}$ \\
\hline $\begin{array}{l}\text { Water } \\
\text { distribution }\end{array}$ & $\begin{array}{l}\text { the water discharge of } \\
\text { Bengawan Solo River } \\
\text { during a long dry season } \\
\text { decreases at times }\end{array}$ & $\begin{array}{l}\text { notifying the } \\
\text { Bengawan Solo River } \\
\text { Basin managers about } \\
\text { this problem }\end{array}$ \\
\hline $\begin{array}{l}\text { Irrigation } \\
\text { network }\end{array}$ & $\begin{array}{l}\text { every year, damages are } \\
\text { caused by mud deposit and } \\
\text { garbage coming into the } \\
\text { irrigation network due to } \\
\text { flood }\end{array}$ & $\begin{array}{l}\text { allocating fund for } \\
\text { irrigation network } \\
\text { repair }\end{array}$ \\
\hline Pump & $\begin{array}{l}\text { breakdown of equipment } \\
\text { (pump as well as other } \\
\text { equipment) }\end{array}$ & $\begin{array}{l}\text { allocating fund for the } \\
\text { repair and purchase of } \\
\text { new pump }\end{array}$ \\
\hline $\begin{array}{l}\text { Pests and diseases } \\
\text { of rice crops }\end{array}$ & $\begin{array}{l}\text { pest and disease attacks } \\
\text { occur most often during } \\
\text { the rainy season }\end{array}$ & $\begin{array}{l}\text { 1) allocating fund for } \\
\text { eradicating pests and } \\
\text { diseases of rice crops } \\
\text { 2) cooperating with } \\
\text { farmer groups, field } \\
\text { counselling officers, } \\
\text { and the Office of } \\
\text { Agriculture for } \\
\text { eradicating pests and } \\
\text { diseases }\end{array}$ \\
\hline Others & & \\
\hline
\end{tabular}

Source: own study.

Some issues in the agricultural irrigation management as outlined in Table 5 can be overcome by planning budget and establishing cooperation between stakeholders. For example, for issue number 5 which is related to pump, the breakdown of the equipment can be prohibited by scheduling more frequent cleaning, i.e. using a chemical clean with hypochlorite every three months [FYLYPCHUK et al. 2017]. The following is Figure 3, which is about the stakeholders in problem solving. 


\section{CONCLUSIONS}

The WUAs in the villages of Plumpang District near the estuary of the Bengawan Solo River use a water pump to channel water from the river. WUA Sekarpadi of Bandungrejo Village is one of the WUAs in Plumpang District that has successfully managed the agricultural irrigation in Bandungrejo village, Magersari village, and Plumpang village. This success is proven by the cash saved in Bank Rakyat Indonesia in a fairly big amount ( $\mathrm{Rp}$ $734,842,355$; approx. USD 55,000). The main source of finance is the contribution from the members. The productivity of rice crops in this village is fairly high, which is around $10-14 \mathrm{t}^{\mathrm{ha}} \mathrm{h}^{-1}$. The continuity of WUA in managing the agricultural irrigation management in this village can be seen from the plan and realization of programs, supported by the funds from the WUAs.

One of the main factors leading to WUAs success is the characteristics of stakeholders in managing agricultural irrigation and solving some issues. The following are the characteristics of WUAs stakeholders: 1) the results of the analysis using a Likert Scale showed that the power index reached a value of 0.76 , while the interest index reached a value of 0.78 ; these values showed the extent of power and interest of the stakeholders in the irrigation water management and farm business activities; 2) the mapping of internal stakeholders, especially the responsibilities and obligations, has been regulated under the articles of incorporation of WUAs; the responsibilities and obligations of external stakeholders, especially the government in making government regulations, in providing support for the agricultural irrigation management in the village should be improved, for example the support for the irrigation infrastructure, flood prevention, and so forth; 3 ) cooperation of the stakeholders has an important role in the agricultural irrigation management and in solving the problems faced by WUAs.

As a recommendation, the research of the impact of WUAs success should be conducted because 1) it provides fund contribution to village development and village administration, and incentives for the people as specified in the progress report of revenue sharing; 2) it is useful for constructing and repairing irrigation infrastructure (tertiary irrigation network), and so forth as specified in the WUAs program implementation; 3) the agricultural irrigation management model using a pump can be implemented in the villages in river basin.

\section{REFERENCES}

AlCAMO J., FlÖRKE M., MäRKER M. 2007. Future long-term changes in global water resources driven by socio-economic and climatic changes. Hydrological Sciences Journal. No 52 (2) p. 247-275.

Anggaran Dasar KPA Sekarpadi, Desa Badungrejo, Kecamatan Plumpang, Kabupaten Tuban [Articles of Incorporation of WUAs Sekarpadi of Bandungrejo village, Plumpang District, Tuban Regency]. March 2014 pp. 22.

ARIEL D. 2016. Drip vs pivot - An economic comparison of irrigation systems based on the whole-farm budget model of sugarcane crops. Woda-Środowisko-Obszary Wiejskie. T. 16. Z 4(56) p. 5-16.

BOURDIEU P. 1983. Form of capital. In: Handbook of theory and research for the sociology of education. Ed. J.C. Richars. New York. Greenwords and Press. ISBN 978-0313235290 p. 241-258.

BRYSON J. M. 2004. What to do when stakeholders maters? Management Review. No. 8(1) p. 21-53.

De Fraiture C., Wichelns D. 2010. Satisfying future water demands for agriculture. Agricultural Water Management. No. 97 (4) p. 502-511.

EDQuist C. 1985. Capitalism, socialism and technology: A comparative study of Cuba and Jamaica. London. Zed Books. ISBN 978-0862323943 pp. 182.

El Chami D., Scardigno A., Zagnoli G., Malorgio G. 2011. Integrated irrigation water policies: Economic and environmental impact in the "Renana" reclamation and irrigation board, Italy. New Medit. No. 10(2) p. 25-32.

FOXTON F., JONES R. 2011. Social capital indicators review [online]. Office for National Statistics pp. 7. [Access 20.08.2018]. Available at: https://webarchive. nationalarchives.gov.uk/20160110075800/http://www.ons. gov.uk/ons/dcp171766_233738.pdf

FREEMAN R.E. 1984. Strategic management: A stakeholders approach. Boston. MA. Pitnam. ISBN 978-0-521-15174-0 pp. 276.

FUKUYAMA F. 1995. Trust: The social virtues and creation of prosperity. New York. Simon and Schuster. ISBN 0-68482525-2 pp. 457.

FylypchuK V., Induchny S., PeARCE P., Fylypchuk L., MARTYNOV S. 2017. Application of expanded polystyrene filter for tertiary treatment of domestic waste effluent in the UK. Journal of Water and Land Development. No 35 (1) p. 41-47. DOI 10.15.15/jwld-2017-0066.

GranOvetTeR M. 1973. The strength of weak ties. American Journal of Sociology. No. 78 p. 1560-1580.

Grimble R., Wellard, K. 1997. Stakeholder methodologies in natural resource management: A review of principles, contexts, experiences and opportunities. Agricultural Systems. No. 55(2) p. 173-193.

IDRIS M. 2017. RI Impor Beras di Awal Tahun 2017, Paling Banyak dari Pakistan [The Republic of Indonesia imported rice mostly from Pakistan] [online]. Finance Detik. [Access 02.05.2018]. Available at: https://finance.detik.com/beritaekonomi-bisnis/d-3448448/ri-impor-beras-di-awal-tahun2017-paling-banyak-dari-pakistan

KASAAI M.R. 2014. Use of water properties in food technology: A global review. International Journal of Food Propertie. No. 17 (5) p. 1034-1054.

Kesepakatan Rapat Umum KPA Sekarpadi, No. 03/1/HIPPA. SEKARPADI/2017 [Resolution of General Meeting of WUA Sekarpadi No. 03/1/HIPPA.SEKARPADI/2017]. March 2017 pp. 12.

Laporan Badan Pengawas KPA Sekarpadi, Desa Badungrejo, Kecamatan Plumpang [Report of Supervisory Body of WUA Sekarpadi, Bandungrejo Village, Plumpang District]. May 2017 pp. 8.

Laporan Kemajuan KPA Sekarpadi, Desa Badungrejo, Kecamatan Plumpang, Kabupaten Tuban, Periode Musim Panen II 2015-2017 [Progress Report of WUAs Sekarpadi of Bandungrejo Village, Plumpang District, Tuban Regency, Harvest Season Period II 2015-2017]. December 2017 pp. 24.

MoRgEnTHAU H.J. 1997. Politics among nations: The struggle for power and peace. $6^{\text {th }}$ ed. Singapore. McGraw-Hill. ISBN 9788170964674 pp. 688.

Morris M.L., TRIPP R.B., DANKYI A.A. 1999. Adoption and impacts of improved maize production technology: A case 
study of the Ghana Grains Development Project. Series: CIMMYT Economics Program Paper. Mexico. CIMMYT pp. 44.

Peraturan Menteri Pekerjaan Umum No. 31/PRT/M/2007 tentang Komisi Irigasi [Regulation of the Minister of Public Works No. 31/PRT/M/2007 about Irrigation Committee]. Jakarta,10 September 2007 pp. 26.

Peraturan Menteri Pekerjaan Umum No. 32/PRT/M/2007 tentang Pemeliharaan Irigasi [Regulation of the Minister of Public Works No. 32/PR/M/2007 about irrigation maintenance]. Jakarta, 11 September 2007 pp. 55.

Peraturan Pemerintah No. 20/2006 tentang Irigasi [Government Regulation No. 20/2006 about irrigation]. Jakarta, 30 May 2006 pp. 60.

Peraturan Menteri Pertanian No. 79/Permentan/OT.140/12/2012 tentang Pedoman Pembinaandan Pemberdayaan Perkumpulan Petani Pemakai Air [Regulation of the Minister of Agriculture No. 79/Permentan/OT.140/12/2012 about guidelinesfor fostering and empowering water user association]. Jakarta, 28 December 2012 pp. 36.

PUTNAM R.D. 2000. Bowling alone: The collapse and revival of American Community. New York. Simon and Schuster. ISBN 978-0743203043 pp. 544.
RUSTINSYAH R. 2015. Social Capital and Implementation of Subsidized Fertilizer Programme for Small Farmers: A case study in rural Java, Indonesia. International Journal of Rural Management. No 11(1) p. 25-39.

RUSTINSYAH R. 2018. The power and interest indicators of the stakeholders of a Water User Association around Bengawan Solo River, Indonesia. Data in Brief. No. 19 p. 2398-2403.

SMALl L.E., CARRUTHERS I. 1991. Farmer-financed irrigation: The economics of reform. Cambridge. Cambridge University Press. ISBN 978-0521062084 pp. 248.

Undang-Undang No. 7/2004 tentang Sumberdaya Air [Law No. 7/2004 about Water Resources] [online]. Jakarta, 18 March 2004. [Access 20.08.2018]. Available at: https://pl.scribd. com/doc/177235630/Bn-Bt-Permentan-79-2012-Lamp

WANG Z., Chen X., YANG T. 2010. Runoff variation and its impacting factors in the Dongjiang River Basin during 19562005. Journal of Natural Resources. No. 25 p. 1365-1374.

World Bank 2012. Sustainable agricultural productivity growth and bridging the gap for small-family farms. Washington, DC pp. 89.

YANG H., Pfister S., Bhaduri A. 2013. Accounting for a scarce resource: virtual water and water footprint in the global water system. Current Opinion in Environmental Sustainability. No. 5(6) p. 599-606.

\section{Rustinsyah RUSTINSYAH, Ratna A. PRASETYO}

\section{Zaangażowanie udziałowców stowarzyszeń użytkowników wód w zarządzanie nawodnieniami rolniczymi we wsiach Indonezji}

\section{STRESZCZENIE}

Rozbudowa i wzmacnianie stowarzyszeń użytkowników wód jest regulowane przez Ministerstwo Rolnictwa Indonezji od 2012 r. Wdrażanie jego zaleceń przybiera jednak różną postać. Niektóre stowarzyszenia osiągnęły sukces, inne nie. W niniejszej publikacji opisano, w jaki sposób omawiane stowarzyszenia we wsiach, które korzystają z wody rzeki Bengawan Solo osiągnęły sukces w zarządzaniu nawodnieniami. Jednym ze źródeł sukcesu jest zaangażowanie udziałowców w rolnicze zarządzanie nawodnieniami i w produkcję rolniczą. Badania prowadzono od czerwca 2016 do czerwca 2017 r. stosując podejście jakościowe. Celem było zidentyfikowanie i zrozumienie zaangażowania interesariuszy w zarządzanie nawodnieniami poprzez: 1) przeprowadzenie analizy siły wpływu i poziomu zainteresowania interesariuszy, 2) zmapowanie pozycji, odpowiedzialności i zobowiązań interesariuszy oraz 3) zidentyfikowanie zaangażowania interesariuszy w zarządzanie rolniczymi nawodnieniami. Na podstawie analizy z wykorzystaniem skali Likerta stwierdzono, że siła wpływu interesariuszy wynosiła 0,76, a poziom zainteresowania - 0,78. Mapowanie wewnętrznych interesariuszy, w szczególności odpowiedzialności i zobowiązania, są regulowane artykułami o włączeniu stowarzyszeń, a zobowiązania zewnętrznych interesariuszy, głównie rządu; polegają na tworzeniu uregulowań prawnych, wsparciu infrastruktury nawodnieniowej i ochronie przeciwpowodziowej. Współpraca interesariuszy odgrywa znaczącą rolę w zarządzaniu nawodnieniami rolniczymi i w rozwiązywaniu problemów, które stają przed stowarzyszeniami użytkowników wód.

Slowa kluczowe: Indonezja, obszary wiejskie, stowarzyszenie użytkowników wód, zaangażowanie interesariuszy, zarzadzanie nawodnieniami rolniczymi 